\title{
No clastogenic activity of Caesalpinia ferrea Mart. (Leguminosae) extract on bone marrow cells of Wistar rats
}

\author{
Andréa Bêcco de Souza, Lilian Mara Silva Souza, José Carlos Tavares Carvalho and Edson Luis Maistro \\ Universidade José do Rosário Vellano, Faculdade de Farmácia, Alfenas, MG, Brazil.
}

\begin{abstract}
Extracts of the fruits of Caesalpinia ferrea Mart. (Leguminosae) are widely consumed in folkloric medicine in Brazil and several other countries without any genetic toxicity evaluation. In this study we investigated, the clastogenic and cytotoxic potential of the crude aqueous extract of the fruits of $C$. ferrea in Wistar rat bone marrow cells using the micronucleus and chromosomal aberration test systems. The animals were treated by gavage with 3 concentrations of the extract, 500, 1000 and $1500 \mathrm{mg} / \mathrm{kg}$, and cyclophosphamide $30 \mathrm{mg} / \mathrm{kg}$. Bone marrow cells were collected $24 \mathrm{~h}$ after the treatment. There was no statistically significant difference in the mean of micronucleated polychromatic erythrocytes (MNPCE), mean number of chromosomal aberrations or mitotic index (MI) for the 3 concentrations compared with negative control suggesting that the crude aqueous extract from the fruits of the $C$. ferrea has no clastogenic and cytotoxic effect in Wistar rat bone marrow cells.
\end{abstract}

Key words: Caesalpinia ferrea; micronucleus test; chromosome aberrations.

Received: November 30, 2004; Accepted: October 24, 2005.

Many plant extracts and their active principles have been described and utilized as therapeutic agents. There is considerable interest in determining the risks that these products may pose to health, because many of these plants contain compounds which are known to cause diseases or even death in animals and humans. Thus, an assessment of their cytotoxic and mutagenic potential is necessary to ensure a relatively safe use of medicinal plants (Surh and Ferguson, 2003).

Caesalpinia ferrea Mart. (Leguminosae) popularly known as "Pau-Ferro" is a large tree that grows throughout Brazil, primarily in Pernambuco and Ceará (Alzugaray, 1984). Some of its therapeutic properties have been described, and include treatment of wounds and bruises, alleviation of chronic cough and asthma (Braga, 1976). The root has been used as an antipyretic agent and the fruit has been used for treatment of diabetics. An infusion of the stem bark has been used for treating enterocolitis and diarrhea (Balbach, 1972). Bacchi and Sertie (1988) described the anti-gastric ulcer effect of an aqueous crude extract of C. ferrea, and its anti-inflammatory and analgesic activity also was reported (Thomas et al., 1988; Carvalho et al., 1996).

In this study, three different concentrations of a crude aqueous extract of the fruits of $C$. ferrea were tested for

Send correspondence to Edson Luis Maistro. Universidade José do Rosário Vellano, Faculdade de Farmácia, Caixa Postal 23, 37130 000 Alfenas, MG, Brazil. E-mail: edson.maistro@unifenas.br. acute clastogenicity in vivo in Wistar rat bone marrow cells, using the chromosome aberration analysis and, as a comparison parameter the micronucleus test.

Plant material was collected in the Icoaracy region, Belém, Pará, Brazil. A voucher specimen (no. 3221) collected by Dr. Antonio Barioni Guzman has been deposited in the herbarium (SPFR) of the Biology Department of the University of São Paulo, Campus Ribeirão Preto, São Paulo, Brazil.

The air-dried fruits were ground and $100 \mathrm{~g}$ of the powder was macerated with water at $60 \pm 10^{\circ} \mathrm{C}$ for $2 \mathrm{~h}$. After filtration, the extract was lyophilized to yield $27.2 \mathrm{~g}$ of crude aqueous extract.

Experiments were carried out on six-week-old Wistar rats (Rattus norvegicus), weighing approximately $100 \mathrm{~g}$. The animals were acquired from the animal house of the University of Alfenas (UNIFENAS), kept in polyethylene boxes $(n=6)$, in a climate-controlled environment ( $25 \pm$ $4{ }^{\circ} \mathrm{C}, 55 \pm 5 \%$ humidity) with a $12 \mathrm{~h}$, light/dark cycle (7 a.m. to 7 p.m.). Food and water were available ad libitum. Rats were divided into experimental groups of six animals each (three males and three females). Caesalpinia ferrea extract was administered in a single dose of $0.5 \mathrm{~mL}$ by gavage at concentrations of 500, 1000 and $1500 \mathrm{mg} / \mathrm{kg}$ body weight, chosen on the basis of the $\mathrm{LD}_{50}$ of $2200 \mathrm{mg} / \mathrm{kg}$ as determined by Carvalho (1993). The negative control group received distilled water and the positive control group received $30 \mathrm{mg}$ of cyclophosphamide/kg. Animals 
were injected intraperitoneally with $0.5 \mathrm{~mL}$ of $0.16 \%$ colchicine $90 \mathrm{~min}$ before euthanasia, which occurred $24 \mathrm{~h}$ after experimental treatment. Both femur bones were excised and the bone marrow flushed into test tubes using a syringe. For the micronucleus (MN) assay, the bone marrow cells from one femur were prepared as recommended by Schimid (1976). The slides were coded, fixed with methanol and stained with Giemsa solution. Two thousand polychromatic erythrocytes (PCE) from each animal were scored for micronucleus (MN) presence. Bone marrow preparations from the other femur were used for the analysis of chromosome aberrations in metaphase cells by the technique of Ford and Hamerton (1956). One hundred metaphases per animal (600 metaphases per group) were analyzed in order to determine the number of chromosomal aberrations in a blind test. The chromosomal aberrations analyzed were gaps, breaks, deletions, fragments, rings and dicentric chromosomes. Since the cytogenetic significance of the gaps still is not well established, the statistical analyses were made including and excluding gaps. The mitotic index (MI), was obtained by counting the number of mitotic cells in the 1000 cells analyzed per animal. The Animal Bioethical Committee of the UNIFENAS approved the present study on January 10, 2004. The data obtained were submitted to the One-way analysis of variance test (ANOVA) and the Tukey-Kramer multiple comparisons test using the GraphPad Instat ${ }^{\circledR}$ software (version 3.01). Results were considered statistically significant at $\mathrm{p}<0.05$.

Table 1 shows the micronucleus test results obtained for female and male Wistar rats treated with C. ferrea extract: the number of micronucleated polychromatic erythrocytes (MNPCE) of each animal and means, for untreated controls and treated animals. The clastogenicity test revealed no enhancement in the mean number of micronucleated polychromatic erythrocytes at any of the tested doses. In contrast, as was expected, cyclophosphamide administered intraperitonealy as positive control at $30 \mathrm{mg} / \mathrm{kg}$ showed a significant increase in the mean number of micronuclei $(\mathrm{p}<0.001)$.
Table 2 shows data on the induction of chromosome aberrations (CA) in dividing bone marrow cells of Wistar rats following in vivo exposure to different doses of $C$. ferrea extract. The table shows the Mitotic Index (MI) and number of different types of CA, mean CAs/treatment including and excluding gaps, for a total of 600 metaphases per dose.

The MI values obtained from the analysis of 1000 cells/animal for a sample of 30 animals $(n=6$ /group) ranged from 1.85 to $2.65 \%$ (means) and statistical analysis by the Tukey-Kramer test showed no significant differences $(\mathrm{p}>0.05)$ between the different treatments with $C$. ferrea extract, or between these treatments and their controls. These data indicate that $C$. ferrea extract has no cytotoxic effects at the tested doses (Table 2).

Treatment of mice infected with Listeria and tumorbearing mice with 500 and $1000 \mathrm{mg} / \mathrm{kg}$ of C. ferrea extract significantly stimulated myelopoiesis, whereas no effects were observed with $250 \mathrm{mg} / \mathrm{kg}$ dose. Similar results were obtained in normal mice (Queiroz et al., 2001). The authors demonstrate that $C$. ferrea extract acts as a positive regulator of white cells, and suggest that therapeutic effects of $C$. ferrea may be partially mediated by this action. In the present work, $C$. ferrea extract did not stimulate cell division.

The anti-tumor promoting effects of fruits of $C$. ferrea were tested in the in vitro Epstein-Barr virus early antigen and showed potent inhibitory activity (Nakamura $e t$ al., 2002a). Gallic acid and methyl gallate isolated from fruits of $C$. ferrea decreased significantly the average number of papilloma mouse showing chemopreventive effects against skin carcinogenesis (Nakamura et al., 2002b).

The data obtained from 100 metaphase cells/animal also showed that there were no statistically significant differences between the mean number of chromosome aberrations (including and excluding gaps) of treated groups and of the negative control $(p>0.05)$. The most frequent types of aberrations of the treated groups were chromatid breaks, chromatid gaps and deletions.

The crude aqueous extract of the fruits of $C$. ferrea was characterized by Carvalho (1993). Contains alkaloids,

Table 1 - Polychromatic erythrocytes with micronuclei (MNPCE) observed in bone marrow cells of female (F) and male (M) Wistar rats treated with a Caesalpinia ferrea extract, and respective controls. Two thousand cells were analyzed per animal, for a total of 12000 cells per group. SEM = standard error of the mean.

\begin{tabular}{|c|c|c|c|c|c|c|c|c|}
\hline \multirow[t]{2}{*}{ Treatments } & \multirow{2}{*}{$\begin{array}{c}\text { Dose } \\
(\mathrm{mg} / \mathrm{kg})\end{array}$} & \multicolumn{6}{|c|}{ Number of MNPCE per animal } & \multirow{2}{*}{$\begin{array}{c}\text { MNPCE } \\
(\text { Mean } \pm \text { SEM })\end{array}$} \\
\hline & & $\mathrm{F}_{1}$ & $\mathrm{~F}_{2}$ & $\mathrm{~F}_{3}$ & $\mathrm{M}_{1}$ & $\mathrm{M}_{2}$ & $\mathrm{M}_{3}$ & \\
\hline Negative control (water) & 0 & 1 & 0 & 0 & 2 & 0 & 1 & $0.66 \pm 0.33$ \\
\hline C. ferrea extract & 500 & 0 & 4 & 1 & 0 & 1 & 0 & $1.00 \pm 0.63$ \\
\hline C. ferrea extract & 1000 & 3 & 0 & 0 & 0 & 0 & 1 & $0.66 \pm 0.49$ \\
\hline C. ferrea extract & 1500 & 0 & 0 & 0 & 1 & 2 & 2 & $0.83 \pm 0.40$ \\
\hline $\begin{array}{l}\text { Positive control } \\
\text { (Cyclophosphamide) }\end{array}$ & 30 & 7 & 5 & 5 & 5 & 6 & 7 & $5.83 * \pm 0.40$ \\
\hline
\end{tabular}

* Significantly different from negative control $(\mathrm{p}<0.001)$. 
Table 2 - Mitotic Index (MI) and distribution of the different types of chromosomal aberrations (CA) observed in female (F) and male (M) Wistar rat bone marrow cells treated with a Caesalpinia ferrea extract, and respective controls. One hundred cells were analyzed per animal, for a total of 600 cells per treatment. C, Chromatid-type; IC, isochromatid-type; OA, other aberrations: del = deletion; $r$ = ring; SEM = standard error of the mean.

\begin{tabular}{|c|c|c|c|c|c|c|c|c|c|}
\hline \multirow[t]{3}{*}{ Treatments } & \multirow[t]{3}{*}{ Sex } & \multirow[t]{3}{*}{ MI (\%) } & \multicolumn{4}{|c|}{ Chromosomal aberrations } & \multirow[b]{3}{*}{$\mathrm{OA}$} & \multirow{3}{*}{$\begin{array}{c}\text { Total (CA) } \\
\text { without gaps }\end{array}$} & \multirow{3}{*}{$\begin{array}{c}\text { Total (CA) } \\
\text { with gaps }\end{array}$} \\
\hline & & & \multicolumn{2}{|c|}{ Gaps } & \multicolumn{2}{|c|}{ Breaks } & & & \\
\hline & & & $\mathrm{C}$ & IC & $\mathrm{C}$ & IC & & & \\
\hline \multirow{7}{*}{$\begin{array}{l}\text { Negative control } \\
\text { (water) }\end{array}$} & $\mathrm{F}_{1}$ & 2.2 & 3 & 1 & 1 & 0 & 0 & 1 & 5 \\
\hline & $\mathrm{F}_{2}$ & 3.4 & 1 & 1 & 2 & 0 & $1 \mathrm{del}$ & 3 & 5 \\
\hline & $\mathrm{F}_{3}$ & 2.8 & 2 & 0 & 1 & 0 & 0 & 1 & 3 \\
\hline & $\mathrm{M}_{1}$ & 1.6 & 2 & 0 & 1 & 0 & 0 & 1 & 3 \\
\hline & $\mathrm{M}_{2}$ & 2.9 & 3 & 0 & 1 & 0 & 0 & 1 & 4 \\
\hline & $\mathrm{M}_{3}$ & 3.0 & 3 & 0 & 1 & 0 & $1 \mathrm{del}$ & 2 & 5 \\
\hline & mean $\pm \mathrm{SEM}$ & $2.65 \pm 0.26$ & & & & & & $1.5 \pm 0.34$ & $4.16 \pm 0.40$ \\
\hline \multirow{7}{*}{$\begin{array}{l}\text { C. ferrea extract } \\
(500 \mathrm{mg} / \mathrm{kg})\end{array}$} & $\mathrm{F}_{1}$ & 1.9 & 2 & 0 & 1 & 0 & 0 & 1 & 3 \\
\hline & $\mathrm{F}_{2}$ & 1.5 & 0 & 0 & 1 & 0 & 0 & 1 & 1 \\
\hline & $\mathrm{F}_{3}$ & 2.3 & 0 & 1 & 2 & 1 & 0 & 3 & 4 \\
\hline & $\mathrm{M}_{1}$ & 2.3 & 2 & 0 & 1 & 0 & 0 & 1 & 3 \\
\hline & $\mathrm{M}_{2}$ & 2.8 & 2 & 0 & 1 & 0 & 0 & 1 & 3 \\
\hline & $\mathrm{M}_{3}$ & 3.1 & 1 & 0 & 0 & 0 & 0 & 0 & 1 \\
\hline & mean $\pm \mathrm{SEM}$ & $2.32 \pm 0.24$ & & & & & & $1.1 \pm 0.40$ & $2.5 \pm 0.50$ \\
\hline \multirow{7}{*}{$\begin{array}{l}\text { C. ferrea extract } \\
(1000 \mathrm{mg} / \mathrm{kg})\end{array}$} & $\mathrm{F}_{1}$ & 1.6 & 0 & 0 & 1 & 0 & 0 & 1 & 1 \\
\hline & $\mathrm{F}_{2}$ & 1.2 & 1 & 0 & 0 & 0 & 0 & 0 & 1 \\
\hline & $\mathrm{F}_{3}$ & 1.7 & 0 & 0 & 1 & 0 & $1 \mathrm{del} / 1 \mathrm{r}$ & 3 & 3 \\
\hline & $\mathrm{M}_{1}$ & 1.8 & 0 & 0 & 2 & 0 & 0 & 2 & 2 \\
\hline & $\mathrm{M}_{2}$ & 2.8 & 2 & 0 & 2 & 0 & $1 \mathrm{del} / 2 \mathrm{r}$ & 5 & 7 \\
\hline & $\mathrm{M}_{3}$ & 2.0 & 0 & 0 & 3 & 2 & $5 \mathrm{del} / 1 \mathrm{r}$ & 11 & 11 \\
\hline & mean $\pm \mathrm{SEM}$ & $1.85 \pm 0.22$ & & & & & & $3.6 \pm 1.62$ & $4.17 \pm 1.64$ \\
\hline \multirow{7}{*}{$\begin{array}{l}\text { C. ferrea extract } \\
(1500 \mathrm{mg} / \mathrm{kg})\end{array}$} & $\mathrm{F}_{1}$ & 2.4 & 1 & 0 & 0 & 0 & 0 & 0 & 1 \\
\hline & $\mathrm{F}_{2}$ & 1.2 & 0 & 0 & 1 & 0 & 0 & 1 & 1 \\
\hline & $\mathrm{F}_{3}$ & 1.6 & 0 & 0 & 1 & 0 & 0 & 1 & 1 \\
\hline & $\mathrm{M}_{1}$ & 1.7 & 1 & 0 & 1 & 0 & 0 & 1 & 2 \\
\hline & $\mathrm{M}_{2}$ & 1.6 & 1 & 0 & 2 & 0 & 0 & 2 & 3 \\
\hline & $\mathrm{M}_{3}$ & 2.6 & 1 & 0 & 1 & 0 & 1 del & 2 & 3 \\
\hline & mean \pm SEM & $1.85 \pm 0.22$ & & & & & & $1.2 \pm 0.31$ & $1.83 \pm 0.40$ \\
\hline \multirow{7}{*}{$\begin{array}{l}\text { Positive control } \\
\text { Cyclophosphamide } \\
(30 \mathrm{mg} / \mathrm{kg})\end{array}$} & $\mathrm{F}_{1}$ & 1.4 & 3 & 0 & 12 & 0 & 2 del & 14 & 17 \\
\hline & $\mathrm{F}_{2}$ & 1.6 & 2 & 2 & 4 & 1 & 0 & 5 & 9 \\
\hline & $\mathrm{F}_{3}$ & 1.8 & 2 & 0 & 12 & 0 & 3 del & 15 & 17 \\
\hline & $\mathrm{M}_{1}$ & 1.8 & 6 & 1 & 14 & 4 & 9 del & 27 & 34 \\
\hline & $\mathrm{M}_{2}$ & 2.5 & 6 & 7 & 12 & 3 & $6 \mathrm{del}$ & 21 & 34 \\
\hline & $\mathrm{M}_{3}$ & 2.4 & 2 & 3 & 14 & 4 & 8 del & 26 & 31 \\
\hline & mean \pm SEM & $1.92 \pm 0.18$ & & & & & & $18.0 * \pm 3.4$ & $23.6 * \pm 4.36$ \\
\hline
\end{tabular}

* Significantly different from negative control $(\mathrm{p}<0.001)$.

anthraquinones, sugars, depsides, depsidones, flavonoids, tannins, saponins, sesquiterpene lactones and triterpenes. Tannins are the majority compounds of the extract and can be considered responsible by the activity against diabetics (Balbachas, 1988; Carvalho, 1993). The analgesic and antiinflammatory effects of the crude extract were confirmed in rodents (Carvalho et al., 1996). Other parts of this plant have been used for other diseases in popular medicine, but their efficiencies need to be further investigated.

The crude aqueous extract from fruits of C. ferrea had its clastogenic potential evaluated for the first time in the present work. The results indicated that the mixture of compounds found in these extracts did not induce a significant increase in the mean number of cells with micronuclei or 
chromosome aberrations when given at the doses of 500, 1000 and $1500 \mathrm{mg} / \mathrm{kg}$ body weight, respectively. Thus, these data permit us to conclude that, under the experimental conditions employed in the present study, the C. ferrea extract had no clastogenic effect in Wistar rat bone marrow cells.

\section{Acknowledgments}

This investigation was financially by FAPEMIG (Rede Mineira de Ensaios Toxicológicos e Farmacológicos de Produtos Terapêuticos, EDT - 1879/02) and UNIFENAS.

\section{References}

Alzugaray D (1984) Plantas que Curam. Hemus Press, São Paulo. Bacchi EM and Sertie JAA (1988) Ação anti-úlcera de Styrax camporum Pohl and Caesalpinia ferrea Mart. Tenth Brazilian Symposium in Medicinal Plants. São Paulo, pp 619.

Balbach A (1972) As Plantas que Curam. Três Press, São Paulo, pp 302-303.

Braga R (1976) Plantas do Nordeste, Especialmente do Ceará. $2^{\mathrm{a}}$ edição. Três Press, São Paulo, pp 45-46.

Carvalho JCT (1993) Caesalpinia ferro (Pau-Ferro): Avaliação da atividade antiinflamatória e analgésica. Masters Thesis. Faculdade de Ciências Farmacêuticas de Ribeirão Preto, Universidade de São Paulo, Ribeirão Preto, 125 pp.

Carvalho JCT, Teixeira JRM, Souza PJC, Bastos JK, Santos-Filho D and Sarti SJ (1996) Preliminary studies of analgesic and anti-inflamatory properties of Caesalpinia ferrea crude extract. J Ethnopharmacol 53:175-178.
Ford CE and Hamerton JL (1956) A colchicine, hypotonic citrate, squash sequence for mammalian chromosomes. Stain Technol 31:247-251.

Nakamura ES, Kurosaki F, Arisawa M, Mukainaka T, Okuda M, Tokuda H, Nishino H and Pastore F (2002a) Cancer chemopreventive effects of constituents of Caesalpinia ferrea and related compounds. Cancer Lett 177:119-124.

Nakamura ES, Kurosaki F, Arisawa M, Mukainaka T, Takayasu J, Okuda M, Tokuda H, Nishino H and Pastore F (2002b) Cancer chemopreventive effects of a Brazilian folk medicine, Juca, on in vivo two stage skin carcinogenesis. J Ethnopharmacol 81:135-137.

Queiroz ML, Justo GZ, Valadares MC and Pereira-da-Silva FR (2001) Evaluation of Caesalpinia ferrea extract on bone marrow hematopoiesis in the murine models of listeriosis and Ehrlich ascites tumor. Immunopharmacol Immunotoxicol 23:367-382.

Schmid W (1976) The micronucleous test for cytogenetic analysis. In: Hollaender A. (ed) Chemical Mutagenesis, Principles and Methods for their Detection. v. 4. Plenum Press, New York, pp 31-53.

Surh Y and Ferguson LR (2003) Dietary and medicinal antimutagens and anticarcinogens: Molecular mechanisms and chemopreventive potential - highlights of a symposium. Mutat Res 523-524:1-8.

Thomas G, Araújo CC and Souza OS (1988) Avaliação das atividades antiinflamatória, analgésica e antipirética dos extratos aquosos de Caesalpinia ferrea, Plantago major, Polygonum acre e Pterodon polygaeflorus. Tenth Brazilian Symposium in Medicinal Plants. São Paulo, Brasil, pp 619. Associate Editor: Catarina S. Takahashi 